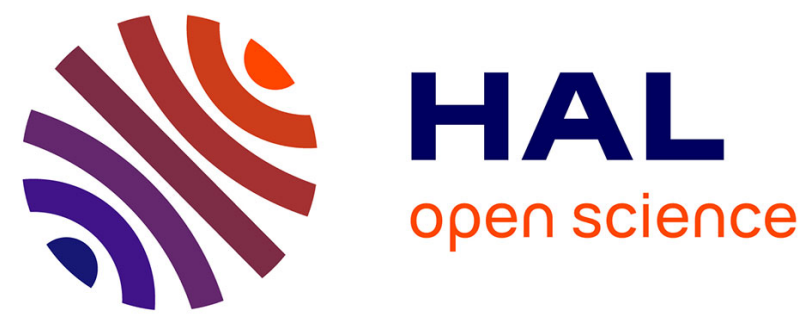

\title{
The Paris Corpus
}

Aliyah Morgenstern, Christophe Parisse

\section{To cite this version:}

Aliyah Morgenstern, Christophe Parisse. The Paris Corpus. Journal of French Language Studies, 2012, 22 (Special issue 1), pp.7-12. 10.1017/S095926951100055X . halshs-01350592

\section{HAL Id: halshs-01350592 \\ https://shs.hal.science/halshs-01350592}

Submitted on 31 Jul 2016

HAL is a multi-disciplinary open access archive for the deposit and dissemination of scientific research documents, whether they are published or not. The documents may come from teaching and research institutions in France or abroad, or from public or private research centers.
L'archive ouverte pluridisciplinaire HAL, est destinée au dépôt et à la diffusion de documents scientifiques de niveau recherche, publiés ou non, émanant des établissements d'enseignement et de recherche français ou étrangers, des laboratoires publics ou privés.

\section{(이) $\$$}

Distributed under a Creative Commons Attribution - NonCommercial - NoDerivatives $\mid 4.0$ 


\title{
The Paris Corpus
}

\author{
Aliyah Morgenstern, Université Sorbonne Nouvelle - Paris 3 \\ Christophe Parisse, MoDyCo, INSERM, CNRS, Université Paris Ouest \\ Nanterre La Défense
}

The Paris corpus ${ }^{l}$ was financed by the Agence Nationale de la Recherche, in the context of two research programs entitled 'Acquisition du Langage et Grammaticalisation' (2005-2008, http://anr-leonard.ens-lsh.fr/) and 'Communication Langagière Chez le Jeune Enfant' (CoLaJE, 2009-2012, http://colaje.risc.cnrs.fr). The aim of the two programs was to collect new French data to enrich the international database of the CHILDES project (MacWhinney, 2000), improve researchers' transcription and coding systems to enable them to study the emergence and development of grammatical patterns used by children between age one and seven, and compare the markers to the use of the same ones in adult speech. The programs brought together specialists from various fields of language acquisition in order to approach language development from a multimodal and interdisciplinary perspective as applied to the same longitudinal data.

1 The recordings and transcriptions can be downloaded from

- $\quad$ http://childes.psy.cmu.edu/data/Romance/French/, or

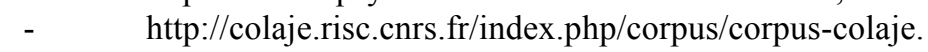


The analyses aimed at finding regularities in acquisition for each child and across the children.

For this special issue of the Journal of French Language Studies, all the authors were given the video recordings and the transcriptions of the same four longitudinal follow-ups. The researchers chose to work on either one or several children within the same data set according to their competence, and conducted studies. Meetings were organized in order to share observations, discuss results and have a better view of the interface between the different levels of children's linguistic development.

\section{THE CHILDREN}

We focused the analyses for this special issue on four children from the Paris Corpus, two girls and two boys. Madeleine was filmed by Martine Sekali from age $0 ; 10^{2}$, Théophile by Aliyah Morgenstern from age 0;07, Antoine by Christophe Parisse from age 0;01 and Anaé by Aliyah Morgenstern and Marie Leroy from age 1;00. The four children are still being filmed and will be until age 7;0. The analyses in this issue are conducted up to $3 ; 0$ and 4;01. All the children live in Paris or in surrounding suburbs. They have middle-class college-educated parents, and were filmed at home about once a month for an hour in daily life situations (playing, taking a bath, having dinner). Madeleine has an older sister, and a brother

\footnotetext{
${ }^{2}$ Age of children is noted as follows: years;months.days.
} 
was born during the course of the recordings. Théophile is a first-born child, and in the course of the recordings a brother and then a sister were born. Antoine is a first-born child and now has a younger brother. Anaé has two older brothers. The parents all worked throughout the data collection period; they used various forms of childcare when the children were young, and the children started going to kindergarten when they were around three years of age.

\section{THE TRANSCRIPTIONS}

The recordings for ages $1 ; 0$ to $3 ; 03$ have already been transcribed and transcriptions up to 5;0 are currently in progress. The new data will be given to CHILDES at the end of the CoLaJE research program. The transcriptions were done in CHAT format ${ }^{3}$, thus enabling the use of CLAN software tools for analyzing and searching the data (Mean Length of Utterance; word frequency; number of word types and word tokens; morphological categorization; word and expression search). The CHAT format enables transcribers to integrate various fields of information. The main symbols to know are the following:

- @ followed by general comments on the situation of the session,

\footnotetext{
3 See Morgenstern and Parisse 2007, and Parisse and Morgenstern 2009 for
} justification and details on the choice of the transcription system. 
- * followed by three capitals to refer to the speaker (example CHI for the target child, MOT for the mother, FAT for the father, BRO for the brother, FRI for a friend of the family or the three first letters of their name).

- \% followed by a three letter code for secondary tiers (pho for phonetic transcription, act for action, gaz for gaze, sit for situation). Transcribers can use as many existing secondary tiers as they need from the user guide or create more codes.

- yy is used when a syllable cannot be identified but can be transcribed phonetically (is it then transcribed in the \%pho line). yyy is used when the meaning of a longer string is not recognized by the transcriber.

Example

@Situation: $\quad \mathrm{CHI}$ and MOT are seated at the table.

*MOT: j'ai fait rouge. [l used red]

\%act: MOT draws.

*MOT: c'est fini. [it's finished]

\%act: MOT takes her hand away from the paper. $\mathrm{CHI}$ violently shakes his head.

${ }^{*} \mathrm{CHI}$ : yy donne. [give]

\%pho: ma don

\%act: $\mathrm{CHI}$ tries to take the pen away from mther's hands. 
\%gaz: $\mathrm{CHI}$ towards MOT

\section{INDIVIDUAL DIFFERENCES}

Despite the fact that the four children come from middle-class families and all spend about the same amount of time with their parents and siblings after work, during weekends and vacations, their language development is quite different in many ways. The two girls are more precocious than the two boys. Madeleine's language development has been extremely fast: her phonological system was almost complete at 2;03, nominal and verbal determination, enrichment of her lexicon, complexification of her utterances, are swift. Her logic and argumentation are quite advanced for her age. Her mother has treated her as a full-fledged co-speaker from very early on. Her data has been studied extensively by researchers of the two projects ${ }^{4}$ and various linguistic markers could be analyzed in detail in the first transcription set (from $1 ; 0$ to $3 ; 03$ ). Ana é's language development is extremely interesting: it has also been quite fast, and she often makes remarkable nonstandard productions that provide clues about how she processes and analyzes the input (Leroy, 2010). The mother and child have a very engaging relationship, with a lot of complicity and humor. Théophile's household is quite a fun place to be raised in, full of music and

\footnotetext{
${ }^{4}$ See for example Morgenstern (2006; 2009); Morgenstern and Sekali 2009; Leroy et al. 2009; Mathiot et al. 2009.
} 
laughter. His language development was slow at first, but at 5;0, he has now become a talkative little boy and has quite a lot of humor. It has been interesting for the researchers to observe the linguistic processes budding and blossoming over a long period of time. Antoine is a cautious little boy, whose productions are quite infrequent but varied and with few deviations from the target. He is very attentive to his interlocutors and his environment, and reacts with a lot of sensitivity and humor to his family's input.

Figures 1 to 4 below show various objective measures used to compare the four children's language development, many of which are used in the analyses presented in this special issue: Mean Length of Utterance, number of word types, number of word tokens, and number of utterances according to age.

Figure 1. Mean Length of Utterance per hour of recording according to age Figure 2: Number of word types per hour of recording according to age Figure 3: Number of words per hour of recording according to age Figure 4: Number of utterances per hour of recording according to age

The four measures shown in the figures reflect a large degree of variation across the different recording situations Madeleine's language productions (black) are richer overall than the other children's, though Anaé (dotted black) is more talkative during certain recordings. Théophile's 
productions (dotted grey) are the least rich and numerous, but towards the end of the recordings, he seems to become more talkative (more utterances than Madeleine in some recordings, MLU higher than Anaé's at some points). Antoine (grey) is a very steady and measured speaker, but he seems to catch up with Anaé, at least as of the recordings around the age of $3 ; 0$. It will be very interesting to compare the four children between $3 ; 0$ and $5 ; 0$ to see if the rate of acquisition between $1 ; 0$ and $3 ; 0$ has any impact on the quantity and quality of their later productions.

These measures provide a general overview of the various children's language development. The quantitative and qualitative analyses conducted in this issue on various aspects of their grammatical development explore important specific features of their individual pathways towards full mastery of their target language.

\section{REFERENCES}

Leroy-Collombel, M. (2010). Eveil de la conscience grammaticale chez un enfant français entre 18 mois et 3 ans. Neveu F., Muni Toke V., Durand J., Klingler T., Mondada L., Prévost S. (éds.) Congrès Mondial de Linguistique Française - CMLF 2010. 978-2-7598-05341, Paris, 2010, Institut de Linguistique Française.

Leroy, M., Mathiot, E., \& Morgenstern, A. (2009) Pointing gestures and demonstrative words : Deixis between the ages of one and three. 
Jordan Zlatev, Marlene Johansson Falck, Carita Lundmark and Mats Andrén (Eds.) Studies in Language and Cognition Cambridge Scholars Publishing., pp. 386-404.

MacWhinney, B., 2000, The CHILDES Project: Tools for analyzing talk, 3rd Edition. Vol. 2: The Database, Mahwah, NJ, Lawrence Erlbaum Associates.

Mathiot, E. Leroy, M., Limousin, F., \& Morgenstern, A. (2009). Premiers pointages chez l'enfant entendant et l'enfant sourd-signeur : deux suivis longitudinaux entre 7 mois et 1 an 7 mois. In Sandra Benazzo (Ed.). Au croisement de différents types d'acquisition : pourquoi et comment comparer. AILE-LIA N¹. pp. 141-168.

Morgenstern A. with the collaboration of Benazzo, S. ; Leroy, M. ; Mathiot, E. ; Parisse. C. ; Salazar Orvig, A. ; Sekali, M. (2009). L'enfant dans la langue. Presses de la Sorbonne Nouvelle.

Morgenstern, A., \& Parisse, C. (2007). Codage et interprétation du langage spontané d'enfants de 1 à 3 ans. Corpus $n^{\circ} 6$ "Interprétation, contextes, codage", pp. 55-78.

Morgenstern, A., \& Sekali, M. (2009). What can child language tell us about prepositions? A contrastive corpus-based study of cognitive and social-pragmatic factors. Studies in Language and Cognition, Cambridge Scholars Publishing. Editors: Jordan Zlatev, Marlene Johansson Falck, Carita Lundmark and Mats Andrén, pp. 261-275. 
Parisse, C., \& Morgenstern, A. (2010). Transcrire et analyser les corpus d'enfant. In Edy Veneziano, Anne Salazar Orvig, Josie Bernicot (Eds.) Acquisition du langage et interaction. L'Harmattan: Paris, pp. 201-222. 


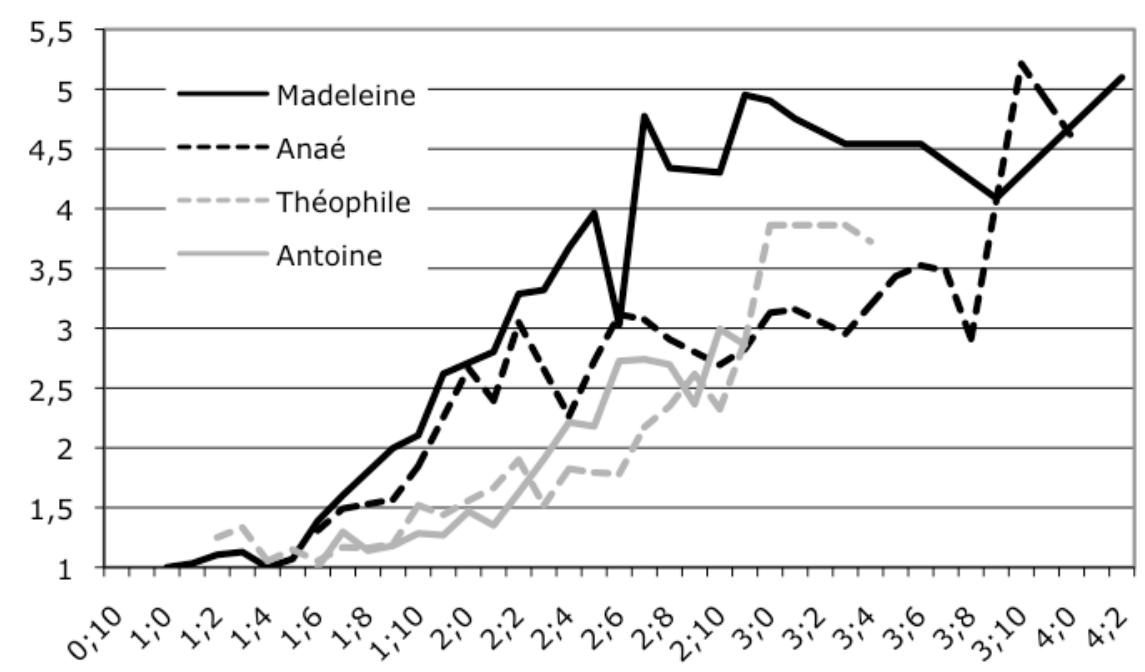

Figure 1. Mean Length of Utterance per hour of recording according to age 


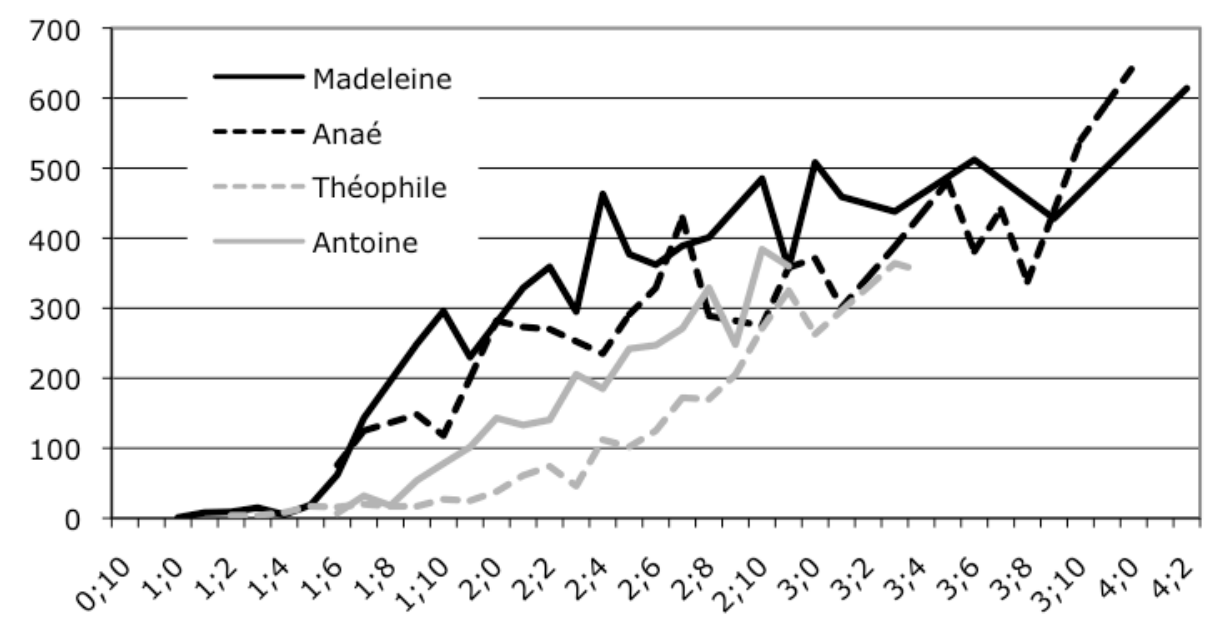

Figure 2: Number of word types per hour of recording according to age 


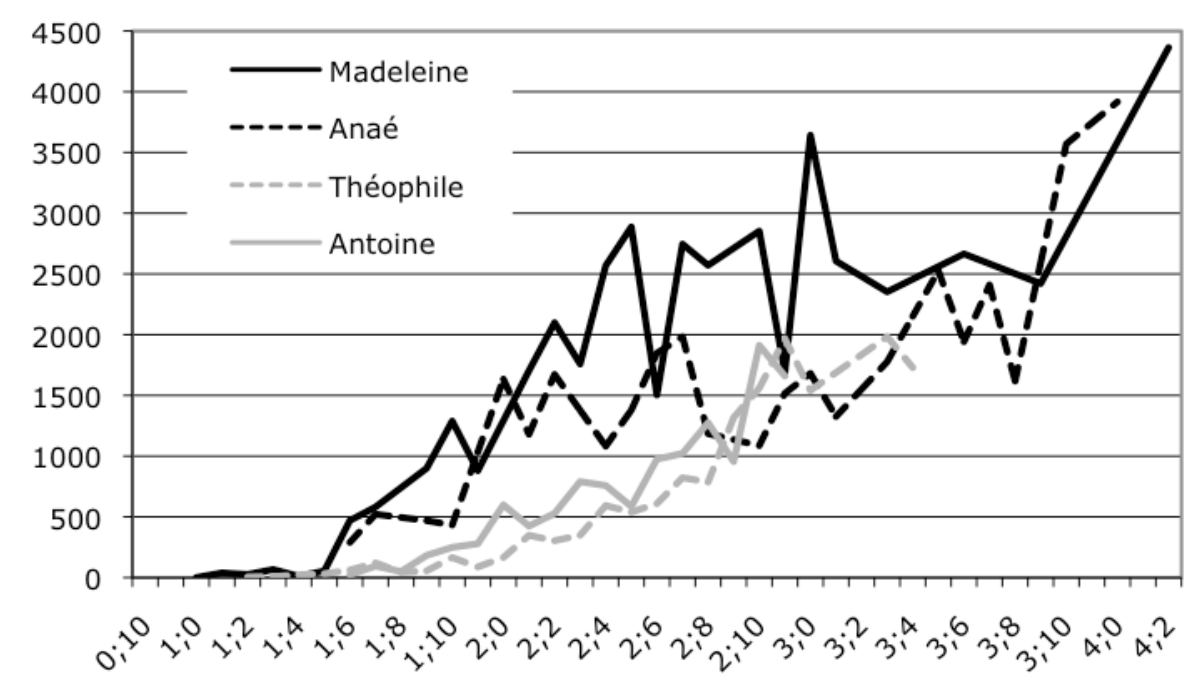

Figure 3: Number of words per hour of recording according to age 


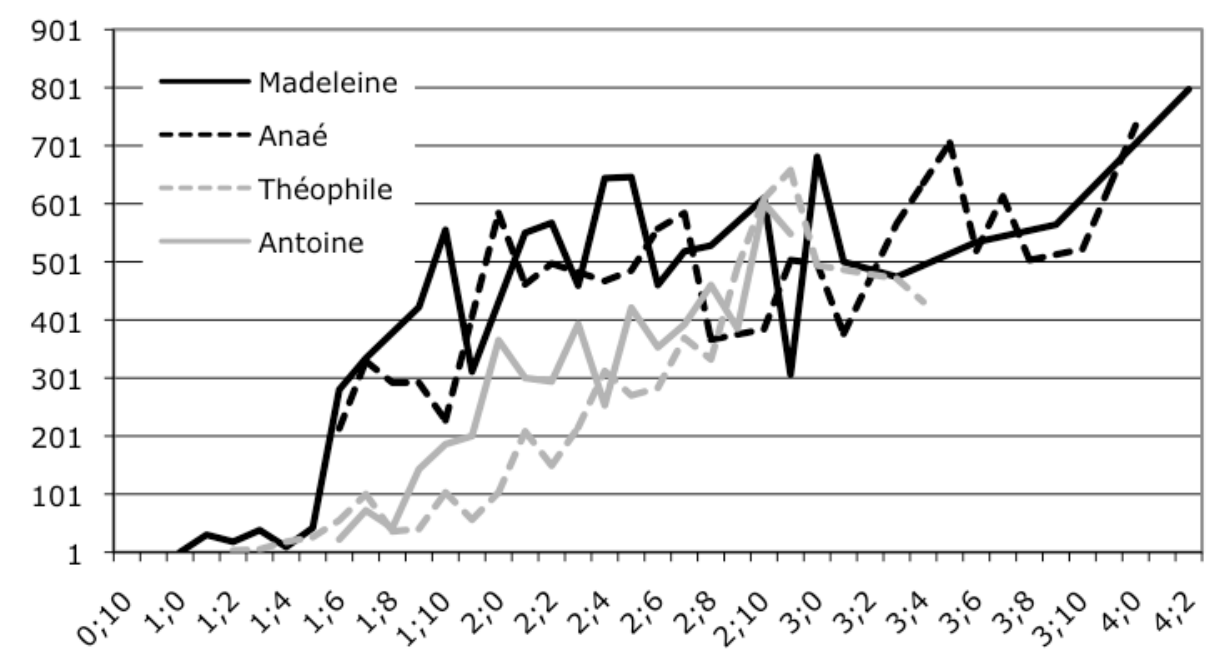

Figure 4: Number of utterances per hour of recording according to age 